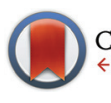

CrossMark $\leftarrow$ click for updates

Cite this: Dalton Trans., 2015, 44 1850

Received 5th November 2014, Accepted 28th November 2014

DOI: $10.1039 / c 4 d t 03403 a$

www.rsc.org/dalton

\section{Complexation of $\mathrm{Cm}(\mathrm{III})$ with the recombinant $\mathrm{N}$-lobe of human serum transferrin studied by time-resolved laser fluorescence spectroscopy (TRLFS)}

\begin{abstract}
N. Bauer, ${ }^{\star a, b}$ V. C. Smith, ${ }^{\text {C R. T. A. MacGillivray }}{ }^{c}$ and P. J. Panak ${ }^{a, b}$
The complexation of $\mathrm{Cm}$ (III) with the recombinant $\mathrm{N}$-lobe of human serum transferrin (hTf/2N) is investigated in the $\mathrm{pH}$ range from 4.0 to 11.0 using TRLFS. At $\mathrm{pH} \geq 7.4 \mathrm{a} \mathrm{Cm}$ (III) $\mathrm{hTf} / 2 \mathrm{~N}$ species is formed with $\mathrm{Cm}(\mathrm{II})$ bound at the Fe(III) binding site. The results are compared with $\mathrm{Cm}(I I)$ transferrin interaction at the $\mathrm{C}$-lobe and indicate the similarity of the coordination environment of the $\mathrm{C}$ - and $\mathrm{N}$-terminal binding sites with four amino acid residues of the protein, two $\mathrm{H}_{2} \mathrm{O}$ molecules and three additional ligands (e.g. synergistic anions such as carbonate) in the first coordination sphere. Measurements at c(carbonate) tot $=0.23 \mathrm{mM}$ (ambient carbonate concentration) and $c$ (carbonate) tot $=25 \mathrm{mM}$ (physiological carbonate concentration) show that an increase of the total carbonate concentration suppresses the formation of the $\mathrm{Cm}$ (III) $\mathrm{hTf} / 2 \mathrm{~N}$ species significantly. Additionally, the three $\mathrm{Cm}(\mathrm{II})$ carbonate species $\mathrm{Cm}\left(\mathrm{CO}_{3}\right)^{+}, \mathrm{Cm}\left(\mathrm{CO}_{3}\right)_{2}^{-}$and $\mathrm{Cm}\left(\mathrm{CO}_{3}\right)_{3}{ }^{3-}$ are formed successively with increasing $\mathrm{pH}$. In general, carbonate complexation is a competing reaction for both $\mathrm{Cm}(\mathrm{II})$ complexation with transferrin and $\mathrm{hTf} / 2 \mathrm{~N}$ but the effect is significantly higher for the half molecule. At c(carbonate) $)_{\text {tot }}=0.23 \mathrm{mM}$ the complexation of $\mathrm{Cm}(\mathrm{II})$ with transferrin and $\mathrm{hTf} / 2 \mathrm{~N}$ starts at $\mathrm{pH} \geq 7.4$. At physiological carbonate concentration the $\mathrm{Cm}$ (III) transferrin species II forms at $\mathrm{pH} \geq 7.0$ whereas the $\mathrm{Cm}(\mathrm{III}) \mathrm{hTf} / 2 \mathrm{~N}$ species is not formed until $\mathrm{pH}>10.0$. Hence, our results reveal significant differences in the complexation behavior of the $\mathrm{C}$-terminal site of transferrin and the recombinant $\mathrm{N}$-lobe $(\mathrm{hTf} / 2 \mathrm{~N})$ towards trivalent actinides.
\end{abstract}

\section{Introduction}

If radionuclides are accidentally released into the environment, they (and in particular actinides) can cause a serious health risk upon incorporation into bodily tissues. Since they have no essential function in the human body little is known about the biochemistry of actinides in man. To allow the development of potential decontamination therapies, a detailed understanding of the mechanisms of relevant biochemical reactions is required. ${ }^{1}$

One potential reaction that absorbed actinides might undergo is the coordination to human serum transferrin.

\footnotetext{
${ }^{a}$ Karlsruhe Institute of Technology (KIT), Campus North, Institute for Nuclear Waste Disposal (INE), P.O. Box 3640, 76021 Karlsruhe, Germany.

E-mail: Nicole.bauer@kit.edu; Fax: (+)49 721608 23927; Tel: (+)49 72160824652

${ }^{b}$ University of Heidelberg, Institute of Physical Chemistry, Im Neuenheimer Feld 253, 69120 Heidelberg; Germany

${ }^{c}$ University of British Columbia, Department of Biochemistry and Molecular Biology and Centre for Blood Research, 2350 Health Sciences Mall, Vancouver,

British Columbia V6 T 1Z3, Canada
}

Transferrin is an iron carrier protein in blood with a molecular mass of 79570 Da consisting of a glycopolypeptide of 679 amino acid residues. ${ }^{2-4}$ The ternary structure of transferrin is characterized by folding into two similar lobes which are joined by a short peptide chain. ${ }^{5}$ Each lobe consists of two domains separated by a cleft housing the metal binding site for $\mathrm{Fe}(\mathrm{III})$. In both lobes $\mathrm{Fe}(\mathrm{III})$ is coordinated by two tyrosines, one aspartate, one histidine and the synergistic anion carbonate in a distorted octahedral geometry. ${ }^{6,7}$ Coordination of $\mathrm{Fe}(\mathrm{III})$ and carbonate at the binding site leads to a conformational change of transferrin from an open to a closed form. This structural change stabilizes the transferrin metal ion complex and is important for the recognition of the metal ion transferrin complex by the receptor. ${ }^{2,8}$

In blood, transferrin is about $30 \%$ saturated with iron. Consequently, non-saturated transferrin is available for the complexation of other metal ions. Besides ferric iron about 30 other metal ions have been identified to bind to transferrin, among them actinides such as $\mathrm{Th}(\mathrm{rv}), \mathrm{Pa}(\mathrm{v}), \mathrm{U}(\mathrm{vr}), \mathrm{Np}(\mathrm{Iv}), \mathrm{Np}(\mathrm{v})$, $\mathrm{Pu}(\mathrm{IV}), \mathrm{Am}(\mathrm{III})$ and $\mathrm{Cm}(\mathrm{III}) .{ }^{9-20}$ In our previous study, the complexation of $\mathrm{Cm}$ (III) with transferrin was studied in the $\mathrm{pH}$ 
range from 3.5 to 11.0 at ambient carbonate concentration. ${ }^{15}$ At $\mathrm{pH} \geq 7.4 \mathrm{Cm}$ (III) is bound at the $\mathrm{Fe}(\mathrm{III})$ binding site of transferrin (Cm(III) transferrin species II) whereas at lower $\mathrm{pH}$ a nonspecific partially bound $\mathrm{Cm}$ (III) transferrin species is formed (Cm(III) transferrin species I). ${ }^{15}$ The fluorescence spectrum of the $\mathrm{Cm}$ (III) transferrin species II is in very good agreement to the spectrum of $\mathrm{Cm}_{2} \mathrm{Tf}$ (Cm(III) bound at the $\mathrm{C}$ - and $\mathrm{N}$-terminal binding sites) and $\mathrm{Cm}_{\mathrm{C}} \mathrm{Tf}(\mathrm{Cm}$ (III) bound only at the C-terminal binding site) observed by Sturzbecher-Hoehne et al. at $\mathrm{pH}$ 8.6. ${ }^{16}$ Furthermore, the influence of carbonate on the complexation of $\mathrm{Cm}(\mathrm{III})$ with transferrin was investigated. ${ }^{21} \mathrm{An}$ increase of the total carbonate concentration favors the formation of the Cm(III) transferrin species II with Cm(III) bound at the $\mathrm{Fe}(\mathrm{III})$ binding site of transferrin at significantly lower $\mathrm{pH}$ values which proves directly that carbonate acts as synergistic anion for $\mathrm{Cm}(\mathrm{III})$ complexation with transferrin. On the other hand, at high carbonate concentration (25 mM) carbonate complexation is an important competition reaction which suppresses Cm(III) transferrin complex formation significantly. ${ }^{21}$

Although the binding ligands are conserved in the $\mathrm{C}$ - and $\mathrm{N}$-terminal binding sites of transferrin, the sites are not kinetically or thermodynamically equivalent. The stability constants for the $\mathrm{N}$ - and C-lobe of $\mathrm{Fe}_{2} \mathrm{Tf}$ differ significantly $\left(\log K_{\mathrm{C}}=21.4\right.$ and $\left.\log K_{\mathrm{N}}=20.3\right),{ }^{22}$ and the difference is almost two orders of magnitude for $\mathrm{Cm}_{2} \mathrm{Tf}\left(\log K_{\mathrm{C}}=8.8 \pm 0.3\right.$ and $\log K_{\mathrm{N}}=7.0 \pm 0.1$ at $\mathrm{pH}$ 8.6). ${ }^{16}$ Therefor a high excess of transferrin was used in the previous studies to ensure exclusive coordination of $\mathrm{Cm}$ (III) at the C-terminal binding site and the formation of a $\mathrm{Cm}$ (III) transferrin complex with $1: 1$ stoichiometry. ${ }^{15,21}$ Only transferrin in the closed conformation with two metal ions bound at the Fe(III) binding sites can be brought into the cells via receptor mediated endocytosis. Hence, it is necessary to study the complexation of $\mathrm{Cm}(\mathrm{III})$ with transferrin at both the $\mathrm{C}$ - and $\mathrm{N}$-lobes to achieve detailed information on the complexation properties of the N-terminal binding site compared to the C-terminal site. Since the stability constant of $\mathrm{Cm}$ (III) coordinated at the N-lobe of transferrin is significantly lower compared to the stability constant of the C-lobe it is not possible to achieve the formation of $\mathrm{Cm}_{\mathrm{N}} \mathrm{Tf}$ with exclusive coordination of $\mathrm{Cm}$ (III) at the N-terminal binding site. Therefor the recombinant N-lobe of human serum transferrin (hTf/2N) which features only the $\mathrm{N}$-terminal binding site is used as a model for the $\mathrm{N}$-lobe of transferrin.

In the present study we investigate the complexation of $\mathrm{Cm}$ (III) with hTf/2N. The Cm(III) hTf/ $2 \mathrm{~N}$ complexation is studied in the $\mathrm{pH}$ range from 4.0 to 11.0 at ambient and physiological carbonate concentration and at room temperature as well as at physiological temperature using time-resolved laser fluorescence spectroscopy (TRLFS). This is a very sensitive method to study complexation reactions of lanthanides and actinides in the submicromolar concentration range. ${ }^{23} \mathrm{Cm}$ (III) is used as a representative for trivalent actinides because of its excellent fluorescence properties. ${ }^{24}$ Spectroscopic parameters like shape and position of the emission bands as well as the fluorescence lifetime provide information on the coordination environment of the metal ion and its complex geometry.

\section{Experimental section}

\section{Chemicals and sample preparation}

All protein samples were prepared in Tris-HCl (tris(hydroxymethyl)aminomethane) buffered solutions (10 mM, pH 7.4) with a physiological sodium chloride concentration of $150 \mathrm{mM}$ $\mathrm{NaCl}$ using ultrapure water (Millipore, Billerica, MA, USA; 18.2 $\mathrm{M} \Omega \mathrm{cm}$ ). $\mathrm{Fe}(\mathrm{III}) \mathrm{hTF} / 2 \mathrm{~N}$ was expressed in baby hamster kidney cells and purified from the tissue culture medium as described previously. ${ }^{25}$ The purity of the hTF/2N was confirmed by SDS-polyacrylamide gel electrophoresis and electrospray mass spectrometry. To remove the Fe(III), Fe(III) hTF/2N was added to an excess of $0.5 \mathrm{M}$ sodium citrate, $1 \mathrm{mM}$ nitrilotriacetic acid (NTA) and $1 \mathrm{mM}$ EDTA (ethylenediaminetetraacetate) ( $\mathrm{pH} 4.9)$ and incubated at room temperature for 10 minutes. The resulting apo-hTF/2N was purified using 22 filtration cycles with Amicon Centrifugal Filter Units, $10 \mathrm{kDa}$ (6500 rpm). The protein concentration of the apo-hTf/2N stock solution was determined by UV/Vis spectroscopy at $\lambda=280 \mathrm{~nm}$ using an extinction coefficient of $\varepsilon=38500 \mathrm{M}^{-1} \mathrm{~cm}^{-1} .^{26}$

The $\mathrm{Cm}(\mathrm{III})$ stock solution used for the TRLFS studies $\left(c(\mathrm{Cm})=3.33 \times 10^{-6} \mathrm{M}\right.$ in $\left.\mathrm{H}_{2} \mathrm{O}\right)$ had an isotopic mass distribution of $89.7 \% \mathrm{Cm}-248$, 9.4\% Cm-246, $\leq 1 \% \mathrm{Cm}-243$, Cm-244, Cm-245 and Cm-247. The Cm(III) concentration of the TRLFS samples was fixed at $1.00 \times 10^{-7} \mathrm{M}$ by adding $30 \mu \mathrm{l}$ of the Cm(III) stock solution to $970 \mu \mathrm{l}$ of a Tris-HCl buffered hTf/2N solution with a concentration of $4.85 \times 10^{-6} \mathrm{M}$ resulting in a final $\mathrm{hTf} / 2 \mathrm{~N}$ concentration of $5.00 \times 10^{-6} \mathrm{M}$. Complexation studies were carried out at varying $\mathrm{pH}$ values between 4.0 and 11.0 using $\mathrm{NaOH}$ and $\mathrm{HCl}$ solutions of different concentrations (1.0 M, 0.5 M, 0.1 M, and 0.01 M). TRLFS measurements were performed at room temperature (296 K) and physiological temperature $(310 \mathrm{~K})$. For the measurements at physiological carbonate concentration the samples were prepared with Tris buffer containing $25 \mathrm{mM} \mathrm{NaHCO}$.

\section{Time-resolved laser fluorescence spectroscopy (TRLFS)}

TRLFS was performed using a Nd-YAG (Continuum Surelite Laser) pumped dye laser system (NARROWscan D-R Dye Laser) with a repetition rate of $10 \mathrm{~Hz}$. For excitation of Cm(III) a wavelength of $396.6 \mathrm{~nm}$ was used. Emission spectra were recorded after a delay of $1 \mu$ s to discriminate short-lived fluorescence of organic compounds. The pulse width was set to $1 \mathrm{~ms}$. After spectral decomposition by a spectrograph (Shamrock 303i) with a 1199 lines $\mathrm{mm}^{-1}$ grating the spectra were recorded with an ICCD camera (iStar Gen III, ANDOR) containing an integrated delay controller. For better comparison all spectra are normalized to the same peak area.

For lifetime measurements, the delay time between the laser pulse and the detection of the fluorescence emission was increased continuously with time intervals of $\Delta t=20 \mu \mathrm{s}$. The lifetime $\tau$ is obtained by fitting the fluorescence intensity $I$ as a function of the delay time $\tau$ according to

$$
I(\lambda)=I_{0}(\lambda) \cdot \mathrm{e}^{-t / \tau}
$$


with the initial intensity $I_{0}$ at $t=0$. Using the Kimura equation

$$
n\left(\mathrm{H}_{2} \mathrm{O}\right)=0.65 \frac{1}{\tau}-0.88
$$

the number of water molecules $n\left(\mathrm{H}_{2} \mathrm{O}\right)$ in the first coordination sphere is obtained from the fluorescence lifetime $\tau$ (in $\mathrm{ms}) .{ }^{27,28}$

\section{Results and discussion}

\section{Complexation of $\mathrm{Cm}$ (III) with $\mathrm{hTf} / 2 \mathrm{~N}$ at room temperature and ambient carbonate concentration}

Complexation of $\mathrm{Cm}(\mathrm{III})$ with $\mathrm{hTf} / 2 \mathrm{~N}$ as a function of $\mathrm{pH}$ was investigated at ambient carbonate concentration $\left.(c \text { (carbonate })_{\text {tot }}=0.23 \mathrm{mM}\right)$ and room temperature $(296 \mathrm{~K})$ using two samples with an initial $\mathrm{pH}$ of 7.4 corresponding to physiological blood conditions. The $\mathrm{pH}$ of the samples was adjusted stepwise with $\mathrm{HCl}$ or $\mathrm{NaOH}$, respectively. At each $\mathrm{pH}$ step, a fluorescence spectrum was recorded (Fig. 1, top). The
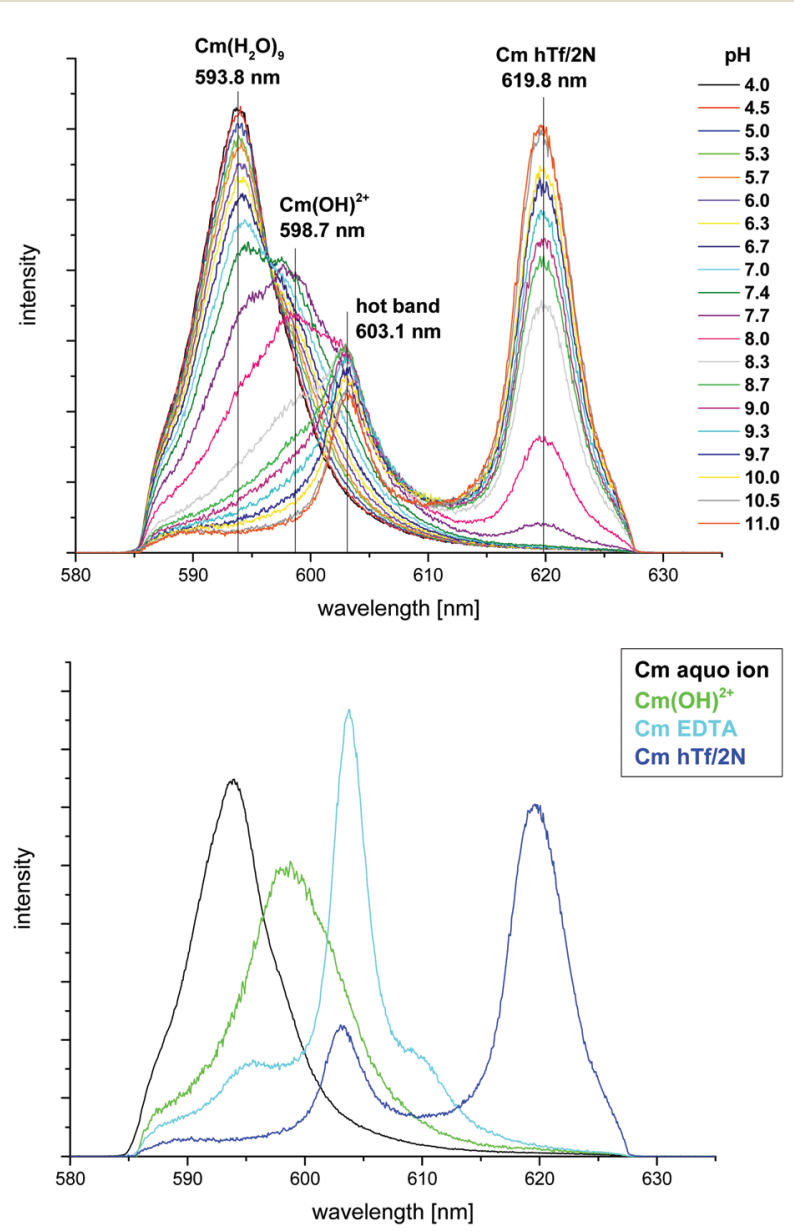

Fig. 1 Top: normalized fluorescence spectra of the $\mathrm{Cm}(\mathrm{III}) \mathrm{hTf} / 2 \mathrm{~N}$ complexation at ambient carbonate concentration and room temperature in the $\mathrm{pH}$ range between 4.0 and 11.0; bottom: normalized fluorescence spectra of the $\mathrm{Cm}$ (III) aquo ion, the first $\mathrm{Cm}$ (III) hydrolysis species, Cm(III) EDTA and the $\mathrm{Cm}(\mathrm{III}) \mathrm{hTf} / 2 \mathrm{~N}$ species; $\mathrm{c}(\mathrm{Cm})=1.0 \times 10^{-7} \mathrm{M}$, $c(\mathrm{hTf} / 2 \mathrm{~N})=5.1 \times 10^{-6} \mathrm{M}, 10 \mathrm{mM}$ Tris, $T=296 \mathrm{~K}$. spectra display a strong $\mathrm{pH}$ dependency of the complexation reaction. Up to $\mathrm{pH} 7.4$ the system is dominated by the $\mathrm{Cm}$ (III) aquo ion, displaying an emission band at $\lambda_{\max }=593.8 \mathrm{~nm} .^{29-31}$ With increasing $\mathrm{pH}$, an emission band at $\lambda_{\max }=598.7 \mathrm{~nm}$ increases which is attributed to the first $\mathrm{Cm}$ (III) hydrolysis species $\mathrm{Cm}(\mathrm{OH})^{2+} \cdot{ }^{32}$ Above pH 7.7 a $\mathrm{Cm}(\mathrm{III})$ hTf/2N complex species is formed and becomes the dominant species for $\mathrm{pH} \geq 8.3$. The spectra display a sharp emission band with an emission maximum at $\lambda_{\max }=620.3 \mathrm{~nm}$ and a hot band at $\lambda_{\max }=603.1 \mathrm{~nm}$. Furthermore, the spectra show the presence of a small amount of a Cm(III) EDTA species displaying an emission maximum at $\lambda_{\max }=603.8 \mathrm{~nm} .{ }^{31}$ The EDTA impurity has its origin in the purification process of apo-hTf/2N.

The emission band of the $\mathrm{Cm}$ (III) hTf/2N complex species is identical to that of the $\mathrm{Cm}$ (III) transferrin species II with $\mathrm{Cm}$ (III) bound at the C-terminal binding site observed in previous studies. ${ }^{15,16,21}$ This species is characterized by very sharp emission bands at $\lambda_{\max }=619.9 \mathrm{~nm}$ and $\lambda_{\max }=602.9 \mathrm{~nm}$ (hot band). The bathochromic shift of the emission band of $26 \mathrm{~nm}$ relative to the emission band of the Cm(III) aquo ion is extraordinary and confirms complexation of $\mathrm{Cm}$ (III) at the $\mathrm{Fe}(\mathrm{III})$ binding site of the protein. ${ }^{15}$ The fluorescence lifetime of the emission band of the $\mathrm{Cm}$ (III) hTf/2N species is determined to be $\tau=217 \pm 5 \mu \mathrm{s}$ which is in very good agreement with the value of the Cm(III) transferrin species II $(\tau=221 \pm 5 \mu \mathrm{s})$ and corresponds to two quenching water molecules in the first coordination sphere. ${ }^{15,16,27,28}$ Assuming an overall coordination number of nine for $\mathrm{Cm}(\mathrm{III})$, the TRLFS results indicate that the first coordination sphere of $\mathrm{Cm}$ (III) complexed with transferrin as well as with $\mathrm{hTf} / 2 \mathrm{~N}$ is composed of four amino acid ligands from the protein, two $\mathrm{H}_{2} \mathrm{O}$ molecules and three additional ligands (e.g. synergistic anions like carbonate). ${ }^{15,16}$ These results show that the coordination environment of $\mathrm{Cm}$ (III) complexed at the C-terminal Fe(III) binding site of transferrin is identical to that of $\mathrm{Cm}(\mathrm{III})$ in the $\mathrm{hTf} / 2 \mathrm{~N}$ complex. The experimental conditions of our previous measurements with transferrin ensure exclusive complexation of $\mathrm{Cm}$ (III) at the binding site of the C-lobe whereas complexation occurs at the N-terminal binding site with $\mathrm{hTf} / 2 \mathrm{~N}$. Hence, our results confirm the similarity of the coordination environment of the binding sites in the $\mathrm{N}$ - and $\mathrm{C}$-lobe of the protein.

In addition to the $\mathrm{Cm}$ (III) transferrin species II, the studies on the complexation of $\mathrm{Cm}$ (III) with transferrin reveal the presence of an unspecific and only partially bound Cm(III) transferrin species with five water molecules and four additional ligands in the first coordination sphere (Cm(III) transferrin species I) which is formed in the $\mathrm{pH}$ range from 3.5 to $9.7 .{ }^{15} \mathrm{In}$ contrast to the measurements with transferrin, no unspecific $\mathrm{Cm}$ (III) species is formed with $\mathrm{hTf} / 2 \mathrm{~N}$. Instead the first $\mathrm{Cm}$ (III) hydrolysis species $\mathrm{Cm}(\mathrm{OH})^{2+}$ is formed in this $\mathrm{pH}$ range. This indicates that the binding of $\mathrm{Cm}(\mathrm{III})$ either occurs on the C-lobe or amino acids from both lobes are involved in the formation of the Cm(III) transferrin species I.

The fluorescence spectra of the pure components (the $\mathrm{Cm}(\mathrm{III})$ aquo ion, $\mathrm{Cm}(\mathrm{OH})^{2+}, \mathrm{Cm}(\mathrm{III})$ EDTA and the $\mathrm{Cm}(\mathrm{III}) \mathrm{hTf} / 2 \mathrm{~N}$ species, Fig. 1 bottom) were determined from the $\mathrm{pH}$ 


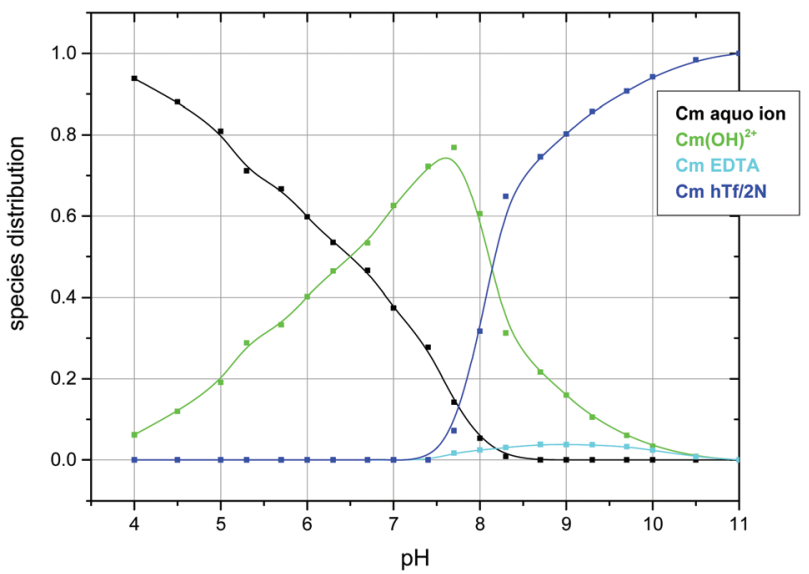

Fig. 2 Speciation of $\mathrm{Cm}(\mathrm{III})$ with $\mathrm{hTf} / 2 \mathrm{~N}$ as a function of $\mathrm{pH}$ at ambient carbonate concentration and room temperature (the curves do not represent mathematical fits but are for guidance only); $c(\mathrm{Cm})=1.0 \times 10^{-7} \mathrm{M}$ and $c(\mathrm{hTf} / 2 \mathrm{~N})=5.1 \times 10^{-6} \mathrm{M}, 10 \mathrm{mM}$ Tris, $T=296 \mathrm{~K}$.

dependent fluorescence spectra. They were used to determine the fractions of the four species at various $\mathrm{pH}$ values by peak deconvolution of the emission spectra. The fluorescence intensity factors $\left(f_{\mathrm{i}}\right.$ factors) which describe the decrease or increase of the fluorescence intensity relative to a reference species, in this case the $\mathrm{Cm}$ (III) aquo ion, have been determined for all $\mathrm{Cm}$ (III) species to be around $1 \pm 0.5$. This means that there is no significant decrease or increase of the fluorescence intensity upon complexation. Nevertheless, the fluorescence intensity factors are taken into account for the calculation of the concentration ratios but the speciation in dependence of $\mathrm{pH}$ (species distribution, Fig. 2) shows no significant change upon consideration of the $f_{\mathrm{i}}$ factors. The $\mathrm{Cm}$ (III) aquo ion is present up to $\mathrm{pH} 8.3$, its concentration decreases with increasing $\mathrm{pH}$, whereas the fraction of the first $\mathrm{Cm}$ (III) hydrolysis species $\mathrm{Cm}(\mathrm{OH})^{2+}$ increases. It is the dominating species in the $\mathrm{pH}$ range from 6.5 to 8.2. At $\mathrm{pH} \geq 7.4$, the $\mathrm{Cm}$ (III) $\mathrm{hTf} / 2 \mathrm{~N}$ species is formed. The formation of this species corresponds to the formation of the $\mathrm{Cm}$ (III) transferrin species II. ${ }^{15}$ Both species are formed at $\mathrm{pH}$ values above 7.4 which underlines the similarity of the C- and N-terminal binding sites. Since the maximum ratio of the Cm(III) EDTA species is about 5\%, it has no significant impact on the speciation and can be neglected.

\section{Kinetics of the complexation reaction and stability of the Cm(III) hTf/2N complex}

Many chelating ligands (such as DOTA (1,4,7,10-tetraazacyclododecane-1,4,7,10-tetraacetic acid)) show slow complexation kinetics. ${ }^{33-36}$ Since the effective ionic radius of $\mathrm{Cm}$ (III) is about two times larger than that of Fe(III), it is expected not to fit exactly into the C- and $\mathrm{N}$-terminal $\mathrm{Fe}(\mathrm{III})$ binding sites of transferrin which might result in slow complexation kinetics. ${ }^{37}$ Therefore, the kinetics of the complexation of $\mathrm{Cm}(\mathrm{III})$ with $\mathrm{hTf} / 2 \mathrm{~N}$ was analyzed at different $\mathrm{pH}$ values in the time range from 0 to 189 hours. Fig. 3 depicts the normalized fluorescence spectra of two $\mathrm{Cm}$ (III) hTf/2N samples at pH 8.0 (top)
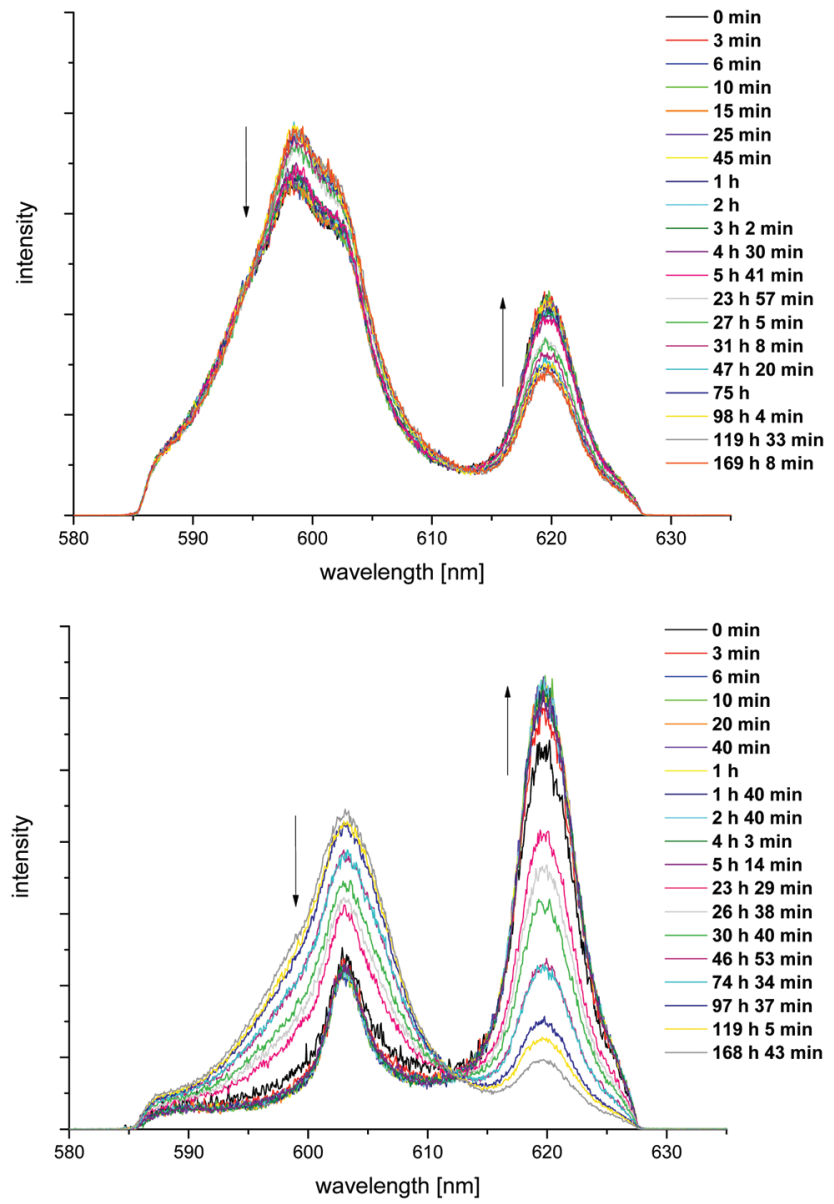

Fig. 3 Normalized fluorescence spectra of the Cm(II) hTf/2N complexation at room temperature and ambient carbonate concentration at $\mathrm{pH}$ 8.0 (top) and pH 10.0 (bottom) as a function of time; $c(\mathrm{Cm})=1.0 \times 10^{-7} \mathrm{M}$ and $c(\mathrm{hTf} / 2 \mathrm{~N})=5.0 \times 10^{-6} \mathrm{M}, 10 \mathrm{mM}$ Tris, time range $0-189 \mathrm{~h}$.

and 10.0 (bottom) with time. Up to a period of 24 hours, the spectra do not change significantly with time which indicates fast kinetics of the complex formation. At both $\mathrm{pH}$ values, equilibrium was reached after five minutes. This is in good agreement with the data on the kinetics of the complexation of $\mathrm{Cm}$ (III) at the C-terminal binding site of transferrin at $\mathrm{pH} 7.4$ and $9.0^{15}$ and confirms fast complexation of $\mathrm{Cm}(\mathrm{mI})$ at the $\mathrm{C}$ - and the $\mathrm{N}$-terminal $\mathrm{Fe}(\mathrm{III})$ binding sites. Therefore, measurements without long-lasting equilibration periods are legitimate for all studies on the interaction of $\mathrm{Cm}$ (III) with transferrin and hTf/2N.

To investigate the stability of the $\mathrm{Cm}$ (III) hTf/2N complex species, fluorescence spectra were recorded after long equilibration times. The spectra of the $\mathrm{Cm}$ (III) transferrin species I and II at pH 7.4 and 9.0 observed in our previous study are unaltered up to 96 hours which indicates the formation of very stable complexes. ${ }^{15}$ In contrast, the spectra of $\mathrm{Cm}$ (III) with $\mathrm{hTf} / 2 \mathrm{~N}$ at $\mathrm{pH} 8.0$ and 10.0 start to change after one day. The emission band of the $\mathrm{Cm}(\mathrm{III}) \mathrm{hTf} / 2 \mathrm{~N}$ species at $\lambda_{\max }=620.3 \mathrm{~nm}$ decreases significantly, in particular at pH 10.0, which indicates decomplexation of $\mathrm{Cm}$ (III) in the time range from 24-189 hours. The results show that the $\mathrm{Cm}$ (III) complex 
formed with the intact transferrin is more stable than that formed with the half molecule. Although the same amino acid residues are present at both binding sites the primary structure of the protein strain is not identical for the $\mathrm{C}$ - and N-lobe ${ }^{4}$ and the stability constants, which are a measure for the complex stability, differ significantly for complexation of $\mathrm{Cm}$ (III) at the $\mathrm{C}$ - and $\mathrm{N}$-terminal binding sites of transferrin $\left(\log K_{\mathrm{C}}=8.8 \pm 0.3\right.$ and $\log K_{\mathrm{N}}=7.0 \pm 0.1$ at $\left.\mathrm{pH} 8.6\right) .{ }^{16}$ This is also reflected in the increased stability of $\mathrm{Cm}$ (III) bound at the C-terminal binding site of transferrin in comparison with the Cm(III) hTf/2N species. The absence of the second lobe seems to have a significant influence on the stability of the protein itself. Decomplexation occurs in the whole $\mathrm{pH}$ range in which the Cm(III) hTf/2N species is present in solution, but the effect is significantly higher when the $\mathrm{pH}$ is increased. Hence, the deprotonation of amino acid residues which might change the structure of $\mathrm{hTf} / 2 \mathrm{~N}$ seems to lead to a further decrease of the stability of the half molecule.

\section{Complexation of $\mathrm{Cm}(\mathrm{III})$ with $\mathrm{hTf} / 2 \mathrm{~N}$ at physiological temperature}

The complexation of $\mathrm{Cm}(\mathrm{III})$ with $\mathrm{hTf} / 2 \mathrm{~N}$ as a function of $\mathrm{pH}$ was investigated at ambient carbonate concentration and physiological temperature $(310 \mathrm{~K})$. The normalized fluorescence spectra in the $\mathrm{pH}$ range from 4.0 to 11.0 (data not shown) are comparable to those observed at room temperature. They display the emission bands of the $\mathrm{Cm}$ (III) aquo ion $\left(\lambda_{\max }=593.9 \mathrm{~nm}\right)$, the first $\mathrm{Cm}(\mathrm{III})$ hydrolysis species $\left(\lambda_{\max }=598.7 \mathrm{~nm}\right)$, the $\mathrm{Cm}(\mathrm{III})$ EDTA species $\left(\lambda_{\max }=603.5 \mathrm{~nm}\right)$ and the $\mathrm{Cm}(\mathrm{III}) \mathrm{hTf} / 2 \mathrm{~N}$ species $\left(\lambda_{\max }=619.9 \mathrm{~nm}\right.$, hot band at $\lambda_{\text {max }}=603.2 \mathrm{~nm}$ ) which are formed successively with increasing $\mathrm{pH}$.

The species concentrations in dependence of $\mathrm{pH}$ (species distribution, Fig. 4) have been determined using the fractions of the different $\mathrm{Cm}$ (III) species derived from peak deconvolution and the fluorescence intensity factors which are around $1 \pm 0.5$. The increase of the temperature from $296 \mathrm{~K}$ to $310 \mathrm{~K}$ has a significant impact on the formation of the different Cm(III)

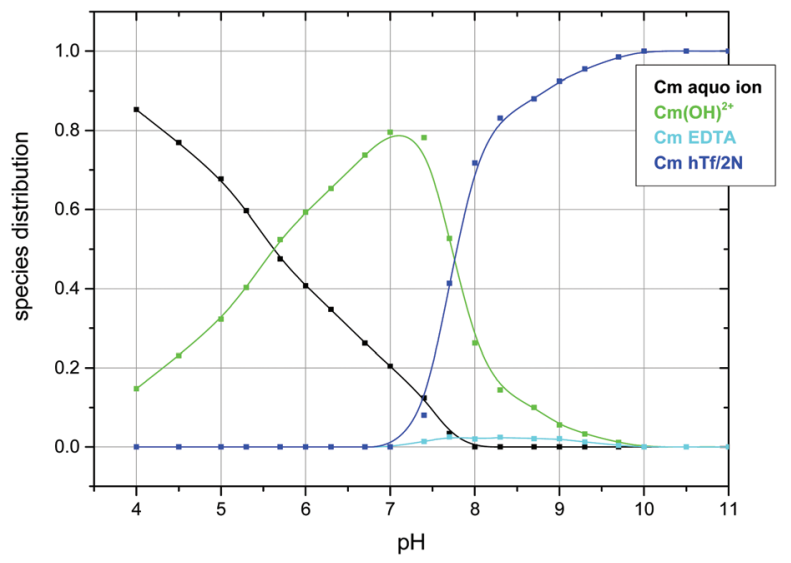

Fig. 4 Speciation of $\mathrm{Cm}(\mathrm{III})$ with $\mathrm{hTf} / 2 \mathrm{~N}$ as a function of $\mathrm{pH}$ at ambient carbonate concentration and physiological temperature (the curves do not represent mathematical fits but are for guidance only); $c(\mathrm{Cm})=1.0 \times 10^{-7} \mathrm{M}$ and $c(\mathrm{hTf} / 2 \mathrm{~N})=5.1 \times 10^{-6} \mathrm{M}, 10 \mathrm{mM}$ Tris, $T=310 \mathrm{~K}$. species. They are formed at $\mathrm{pH}$ values that are about 0.5 units lower than the respective $\mathrm{pH}$ values at room temperature (Fig. 2). At physiological temperature, the Cm(III) hTf/2N species is formed above $\mathrm{pH} 7.0$ whereas the formation starts at $\mathrm{pH} \geq 7.4$ at room temperature conditions. This is comparable to the difference in the formation of the $\mathrm{Cm}$ (III) transferrin species II at these two temperatures. ${ }^{15}$ At $310 \mathrm{~K}$, complex formation also occurs at $\mathrm{pH}$ values that are 0.5 units lower than the respective $\mathrm{pH}$ values at room temperature. The analogy of the temperature dependency of the $\mathrm{Cm}$ (III) complexation with $\mathrm{hTf} / 2 \mathrm{~N}$ and transferrin again underlines the similarity of the $\mathrm{C}$ - and $\mathrm{N}$-terminal binding sites.

\section{Complexation of $\mathrm{Cm}$ (III) with $\mathrm{hTf} / 2 \mathrm{~N}$ at physiological carbonate concentration}

In order to study the influence of carbonate on the complexation of $\mathrm{Cm}$ (III) with $\mathrm{hTf} / 2 \mathrm{~N}$, the complex formation was studied as a function of $\mathrm{pH}$ at physiological carbonate concentration $\left.(c \text { (carbonate })_{\text {tot }}=25 \mathrm{mM}\right)$. The term physiological carbonate concentration describes a total concentration of the species $\mathrm{CO}_{3}{ }^{2-}, \mathrm{HCO}_{3}{ }^{-}$and $\mathrm{CO}_{2 \text { (aq.) }}$ of $c$ (carbonate) $)_{\text {tot }}=25 \mathrm{mM}$ with the speciation of $\mathrm{CO}_{3}{ }^{2-}, \mathrm{HCO}_{3}{ }^{-}$and $\mathrm{CO}_{2 \text { (aq.) }}$ depending on the pH. ${ }^{21}$ Fig. 5 (top) shows the normalized fluorescence spectra in the $\mathrm{pH}$ range from 4.0 to 11.0. At low $\mathrm{pH}$ the spectra are dominated by the emission band of the $\mathrm{Cm}$ (III) aquo ion $\left(\lambda_{\max }=593.9 \mathrm{~nm}\right)$. In contrast to the measurements at ambient carbonate concentration, the emission band of the first $\mathrm{Cm}$ (III) hydrolysis species is not observed under physiological carbonate conditions. Instead, three $\mathrm{Cm}(\mathrm{III})$ carbonate species $\mathrm{Cm}\left(\mathrm{CO}_{3}\right)^{+}, \mathrm{Cm}\left(\mathrm{CO}_{3}\right)_{2}{ }^{-}$and $\mathrm{Cm}\left(\mathrm{CO}_{3}\right)_{3}{ }^{3-}$ with emission maxima at $\lambda_{\max }=598.8 \mathrm{~nm}, 603.2 \mathrm{~nm}$ and $605.8 \mathrm{~nm}$ are formed. ${ }^{32} \mathrm{Com}-$ parison with blank solutions (without hTf/2N) in the same $\mathrm{pH}$ range proves that these emission bands result from $\mathrm{Cm}$ (III) carbonate interactions and do not represent additional transferrin species. The Cm(III) hTf $/ 2 \mathrm{~N}$ species with $\lambda_{\max }=619.7 \mathrm{~nm}$ is formed at $\mathrm{pH} \geq 10.5$ which indicates a distinct competition between carbonate and hTf/2N. Fig. 5 (bottom) shows the fluorescence spectra of the pure components ( $\mathrm{Cm}(\mathrm{III})$ aquo ion, $\mathrm{Cm}\left(\mathrm{CO}_{3}\right)^{+}, \quad \mathrm{Cm}\left(\mathrm{CO}_{3}\right)_{2}{ }^{-}, \quad \mathrm{Cm}\left(\mathrm{CO}_{3}\right)_{3}{ }^{3-}$ and $\mathrm{Cm}(\mathrm{III}) \mathrm{hTf} / 2 \mathrm{~N}$ species). As shown in Fig. 6 (top), the fraction of the Cm(III) aquo ion decreases with increasing $\mathrm{pH}$ whereas up to $90 \%$ of the Cm(III) mono-, di- and tri-carbonate complexes are formed successively. The $\mathrm{Cm}\left(\mathrm{CO}_{3}\right)^{+}$and $\mathrm{Cm}\left(\mathrm{CO}_{3}\right)_{2}{ }^{-}$species dominate the speciation in the $\mathrm{pH}$ range from 5.8 to 7.2 and from 7.2 to 8.9, respectively. Additionally, the $\mathrm{Cm}\left(\mathrm{CO}_{3}\right)_{3}{ }^{3-}$ complex is formed in the $\mathrm{pH}$ range from 7.7 to 11.0 . The Cm(III) hTf/ $2 \mathrm{~N}$ species forms above $\mathrm{pH} 10.0$ at physiological carbonate conditions. In comparison, at ambient carbonate concentration, the complex formation starts at a significantly lower $\mathrm{pH}$ value ( $\mathrm{pH}$ 7.4). Hence, an increase of the carbonate concentration suppresses the formation of the Cm(III) hTf/2N species significantly. This indicates that carbonate complexation is an important competition reaction to the formation of the Cm(III) $\mathrm{hTf} / 2 \mathrm{~N}$ species which has to be considered when complexation studies with hTf/2N are performed at physiological conditions. 

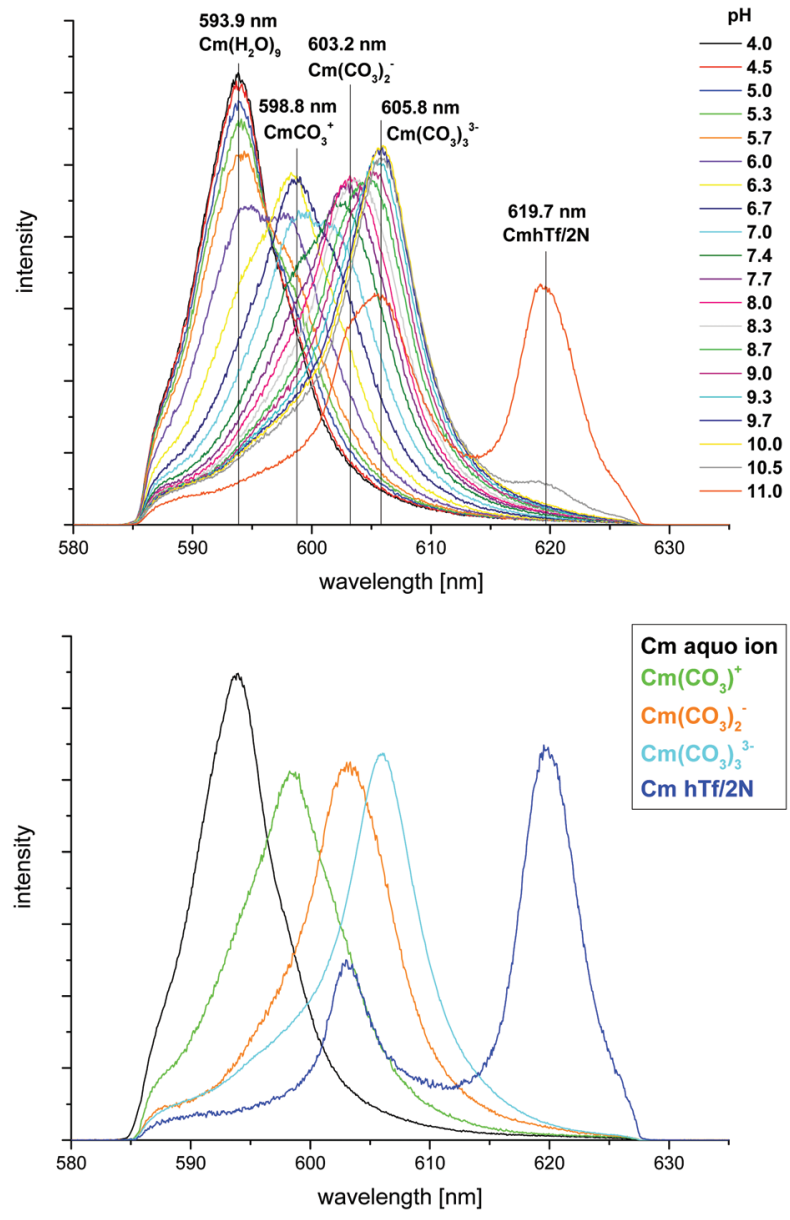

Fig. 5 Top: normalized fluorescence spectra of the $\mathrm{Cm}$ (III) hTf/2N complexation at physiological carbonate concentration and room temperature in the $\mathrm{pH}$ range from 4.0 to 11.0; bottom: normalized fluorescence spectra of the $\mathrm{Cm}$ (III) aquo ion, the $\mathrm{Cm}$ (III) carbonate species and the $\mathrm{Cm}(\mathrm{III}) \mathrm{hTf} / 2 \mathrm{~N}$ species; $c(\mathrm{Cm})=1.0 \times 10^{-7} \mathrm{M}, \mathrm{c}(\mathrm{hTf} / 2 \mathrm{~N})=5.1 \times 10^{-6} \mathrm{M}$ and $c$ (carbonate $)_{\text {tot }}=2.5 \times 10^{-2} \mathrm{M}, 10 \mathrm{mM}$ Tris, $T=296 \mathrm{~K}$.

In addition to the measurements at room temperature, the complexation of $\mathrm{Cm}$ (III) with hTf/ $2 \mathrm{~N}$ as a function of $\mathrm{pH}$ was also studied at physiological carbonate concentration (carbonate $)_{\text {tot }}=25 \mathrm{mM}$ ) and physiological temperature $(310 \mathrm{~K})$. The spectra are very similar to those observed at room temperature conditions. They depict the emission bands of the $\mathrm{Cm}(\mathrm{III})$ aquo ion, the three $\mathrm{Cm}$ (III) carbonate species $\mathrm{Cm}\left(\mathrm{CO}_{3}\right)^{+}, \mathrm{Cm}\left(\mathrm{CO}_{3}\right)_{2}{ }^{-}$ and $\mathrm{Cm}\left(\mathrm{CO}_{3}\right)_{3}{ }^{3-}$ and the $\mathrm{Cm}(\mathrm{III}) \mathrm{hTf} / 2 \mathrm{~N}$ species which are formed successively with increasing $\mathrm{pH}$. The species distribution (Fig. 6, bottom) shows that the Cm(III) aquo ion dominates the speciation up to $\mathrm{pH}$ 5.7. With increasing $\mathrm{pH}$ the $\mathrm{Cm}\left(\mathrm{CO}_{3}\right)^{+}, \mathrm{Cm}\left(\mathrm{CO}_{3}\right)_{2}{ }^{-}$and $\mathrm{Cm}\left(\mathrm{CO}_{3}\right)_{3}{ }^{3-}$ species are formed successively. Compared to room temperature conditions the formation of the $\mathrm{Cm}$ (III) carbonate species starts at slightly lower $\mathrm{pH}$ values. Above $\mathrm{pH} 9.3$ the concentration of the $\mathrm{Cm}(\mathrm{III}) \mathrm{hTf} / 2 \mathrm{~N}$ species increases continuously. In contrast, the formation of the $\mathrm{Cm}$ (III) hTf/2N species at room temperature does not occur until $\mathrm{pH}$ 10.0. Hence, an increase of the temperature favors the complexation of $\mathrm{Cm}(\mathrm{III})$ with $\mathrm{hTf} / 2 \mathrm{~N}$ at lower $\mathrm{pH}$ values.
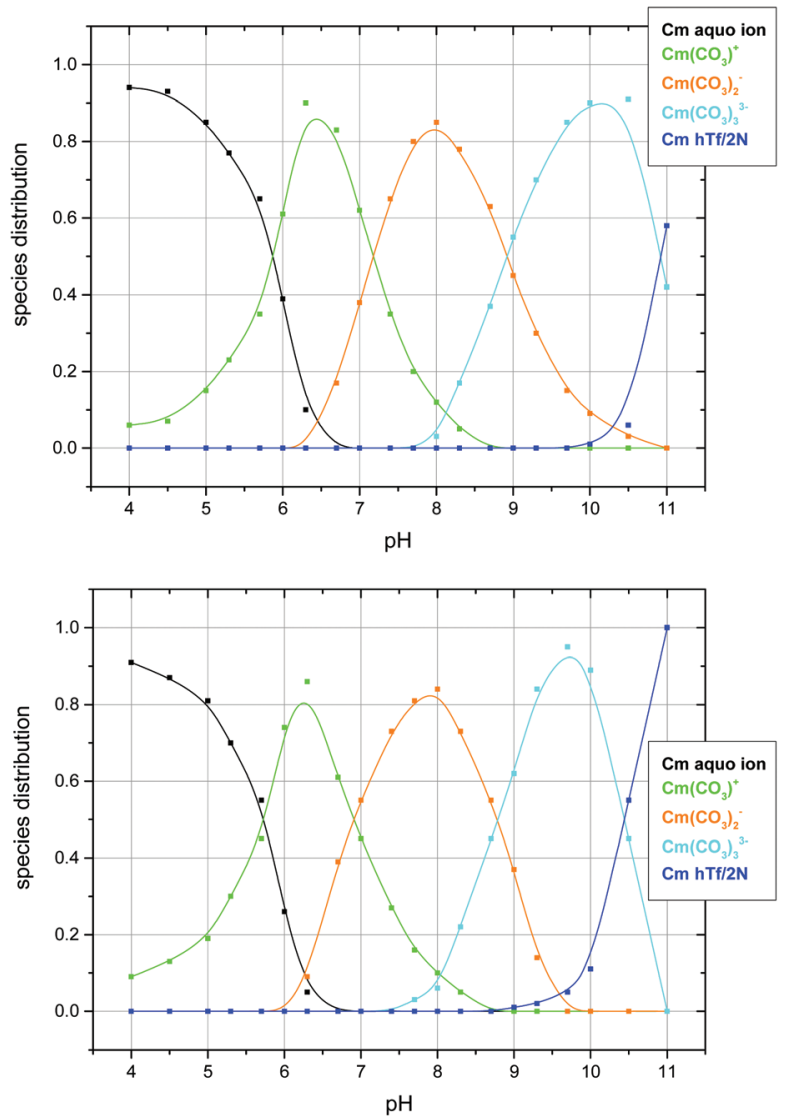

Fig. 6 Speciation of $\mathrm{Cm}(\mathrm{III})$ with $\mathrm{hTf} / 2 \mathrm{~N}$ as a function of $\mathrm{pH}$ at physiological carbonate concentration and room temperature (top) and physiological temperature (bottom); the curves do not represent mathematical fits but are for guidance only; $c(\mathrm{Cm})=1.0 \times 10^{-7} \mathrm{M}$, $c(\mathrm{hTf} / 2 \mathrm{~N})=5.1 \times 10^{-6} \mathrm{M}, c(\text { carbonate })_{\text {tot }}=2.5 \times 10^{-2} \mathrm{M}, 10 \mathrm{mM}$ Tris, $T=296 \mathrm{~K}$ (top) and $T=310 \mathrm{~K}$ (bottom).

The speciation of $\mathrm{Cm}$ (III) $\mathrm{hTf} / 2 \mathrm{~N}$ complexation was compared to the measurements of $\mathrm{Cm}$ (III) transferrin at the same conditions. ${ }^{21}$ While the spectroscopic data on the complexation of $\mathrm{Cm}$ (III) with $\mathrm{hTf} / 2 \mathrm{~N}$ and at the C-terminal binding site of transferrin agree very well at ambient carbonate concentration (complex formation starts at $\mathrm{pH}$ 7.4), the species distributions reveal significant differences at physiological carbonate concentration: at room temperature, the Cm(III) transferrin species II is formed at $\mathrm{pH} \geq 7.0 .^{21}$ This indicates that an increase of carbonate favors the formation of the Cm(III) transferrin species II at lower $\mathrm{pH}$ values, with carbonate acting as a synergistic anion for $\mathrm{Cm}$ (III) complexation at the C-terminal binding site of transferrin. At higher $\mathrm{pH}(\mathrm{pH} \geq 7.4)$, the competing effect of carbonate plays a distinct role resulting in a decrease of the fractions of the Cm(III) transferrin species II. ${ }^{21}$ In the case of $\mathrm{hTf} / 2 \mathrm{~N}$, carbonate complexation suppresses the formation of the $\mathrm{Cm}$ (III) $\mathrm{hTf} / 2 \mathrm{~N}$ species significantly, even at low $\mathrm{pH}$ conditions. For that reason, this species is not formed until $\mathrm{pH}>10.0$ at physiological carbonate concentration. In general, carbonate complexation is a competing reaction for both $\mathrm{Cm}$ (III) complexation with $\mathrm{hTf} / 2 \mathrm{~N}$ and at the C-terminal 
binding site of transferrin but the effect is significantly higher for the half molecule.

There is only deficient knowledge concerning the competitive effect of carbonate on the complexation of metal ions to transferrin. Nevertheless, the competition between carbonate and transferrin has been observed in previous studies for some lanthanide and actinide ions. ${ }^{38-41}$ Based on complexation studies of $\mathrm{Gd}(\mathrm{III})$ with transferrin in vitro, Zak and Aisen suggest that transferrin may not be an important carrier protein for Gd(III) in vivo because of the formation of Gd(III) carbonate complexes. ${ }^{41}$ Taylor et al. reported that only about $20 \%$ of $\mathrm{Eu}(\mathrm{III}), \mathrm{Yb}(\mathrm{III}), \mathrm{Am}(\mathrm{III})$ and $\mathrm{Cm}$ (III) are bound to transferrin in vivo which is also attributed to the competition with carbonate. $^{39,40}$

Although the species distributions reveal significant differences in the complexation behavior of $\mathrm{Cm}$ (III) with the C-lobe of transferrin and $\mathrm{hTf} / 2 \mathrm{~N}$ at physiological carbonate concentration, the temperature dependency of the $\mathrm{Cm}(\mathrm{III}) \mathrm{hTf} / 2 \mathrm{~N}$ complexation reaction is comparable to the data on $\mathrm{Cm}$ (III) $\mathrm{hTf} / 2 \mathrm{~N}$ and $\mathrm{Cm}$ (III) transferrin interaction at ambient carbonate concentration. In general, at physiological temperature $(310 \mathrm{~K})$ the $\mathrm{Cm}(\mathrm{III})$ complexes with $\mathrm{hTf} / 2 \mathrm{~N}$ and the C-terminal binding site of transferrin are formed at $\mathrm{pH}$ values that are 0.5 units lower than the respective $\mathrm{pH}$ values at room temperature (valid for ambient and physiological carbonate conditions). Hence, an increase of the temperature favors the complexation of $\mathrm{Cm}$ (III) with hTf/2N as well as at the C-terminal binding site of transferrin at lower $\mathrm{pH}$ values. This indicates that $\mathrm{Cm}$ (III) transferrin and $\mathrm{Cm}(\mathrm{III}) \mathrm{hTf} / 2 \mathrm{~N}$ complexation are endothermic and entropy-driven reactions.

Because of the potential transport of actinides into cells, the complexation of $\mathrm{Cm}(\mathrm{III})$ with hTf/2N (N-lobe) and transferrin (C-lobe) at physiological conditions $(\mathrm{pH} 7.4, T=310 \mathrm{~K}$, $c$ (carbonate $)_{\text {tot }}=25 \mathrm{mM}$ ) is of particular interest. In the case of hTf/2N, only the $\mathrm{Cm}\left(\mathrm{CO}_{3}\right)^{+}$and $\mathrm{Cm}\left(\mathrm{CO}_{3}\right)_{2}{ }^{-}$species are formed under physiological conditions whereas the formation of the $\mathrm{Cm}$ (III) hTf/2N species is completely suppressed. In contrast, results from our previous study show the formation of about $29 \% \mathrm{Cm}\left(\mathrm{CO}_{3}\right)^{+}, 38 \% \mathrm{Cm}\left(\mathrm{CO}_{3}\right)_{2}{ }^{-}, 18 \% \mathrm{Cm}\left(\mathrm{CO}_{3}\right)_{3}{ }^{3-}$ and $15 \%$ of the $\mathrm{Cm}$ (III) transferrin species II with $\mathrm{Cm}$ (III) bound at the C-terminal binding site under the same conditions. Though the fraction of the $\mathrm{Cm}$ (III) transferrin species II is low compared to the fraction of the $\mathrm{Cm}$ (III) carbonate species, a complex with $\mathrm{Cm}$ (III) bound at the C-terminal binding site of transferrin might be recognized by the receptor followed by endocytosis which could be a possible pathway for the distribution of $\mathrm{Cm}$ (III) in the human body. In general, carbonate is a competitive ligand for both $\mathrm{hTf} / 2 \mathrm{~N}$ and transferrin but the impact on the $\mathrm{Cm}$ (III) hTf/2N species is significantly higher compared to Cm(III) complexation at the C-terminal binding site of transferrin. The different complexation behavior of hTf/ $2 \mathrm{~N}$ and the C-lobe of transferrin at physiological carbonate concentration might either result from the thermodynamic difference of the binding sites $\left(\log K_{\mathrm{C}}=8.8 \pm 0.3\right.$ and $\log K_{\mathrm{N}}=7.0 \pm 0.1$ at $\mathrm{pH}$ $8.6),{ }^{16}$ or from the fact that the presence or absence of the second lobe might have a significant impact on the stability of the protein itself as well as on the regarding $\mathrm{Cm}$ (III) complexes. Nevertheless, the differences in the complexation behavior of $\mathrm{Cm}$ (III) with $\mathrm{hTf} / 2 \mathrm{~N}$ and transferrin underline the inequality of the $\mathrm{C}$ - and $\mathrm{N}$-terminal binding sites.

\section{Conclusions}

In the present study, the complexation of $\mathrm{Cm}(\mathrm{III})$ with the recombinant $\mathrm{N}$-lobe of human serum transferrin $(\mathrm{hTf} / 2 \mathrm{~N})$ was investigated using TRLFS. The results were compared to the measurements on $\mathrm{Cm}$ (III) complexation at the C-terminal binding site of transferrin from previous studies resulting in detailed information on the complexation properties of the Cand N-terminal binding sites. ${ }^{15,21}$ The spectroscopic characteristics of the emission bands show that the Cm(III) hTf/2N species is comparable to the $\mathrm{Cm}$ (III) transferrin species II (Cm(III) complexed at the C-terminal site) which indicates the similarity of the coordination environment of the C- and N-terminal binding sites. In both complexes $\mathrm{Cm}$ (III) is coordinated by four amino acid residues of the protein, two $\mathrm{H}_{2} \mathrm{O}$ molecules and three additional ligands (e.g. synergistic anions like carbonate). ${ }^{15}$

Measurements at physiological carbonate concentration reveal that the synergistic anion carbonate is a competitive ligand for complexation of $\mathrm{Cm}(\mathrm{III})$ with $\mathrm{hTf} / 2 \mathrm{~N}$. This is comparable to the influence of carbonate on $\mathrm{Cm}$ (III) transferrin but the impact on the $\mathrm{Cm}(\mathrm{III}) \mathrm{hTf} / 2 \mathrm{~N}$ species (N-lobe) is significantly higher compared to $\mathrm{Cm}$ (III) complexation at the C-terminal binding site of transferrin. Hence, Cm(III) forms more stable complexes with the C-terminal binding site of transferrin compared to $\mathrm{hTf} / 2 \mathrm{~N}$ which is in good agreement with the thermodynamic difference of the binding sites. ${ }^{16}$ Furthermore, the presence of a second lobe seems to improve the stability of the protein itself and the $\mathrm{Cm}(\mathrm{III})$ complexes significantly.

\section{Notes and references}

1 A. E. V. Gorden, J. D. Xu, K. N. Raymond and P. Durbin, Chem. Rev., 2003, 103, 4207.

2 H. Z. Sun, H. Y. Li and P. J. Sadler, Chem. Rev., 1999, 99, 2817.

3 R. T. A. MacGillivray, E. Mendez, J. G. Shewale, S. K. Sinha, J. Linebackzins and K. Brew, J. Biol. Chem., 1983, 258, 3543.

4 R. T. A. MacGillivray, E. Mendez, S. K. Sinha, M. R. Sutton, J. Linebackzins and K. Brew, Proc. Natl. Acad. Sci. U. S. A., 1982, 79, 2504.

5 J. Wally, P. J. Halbrooks, C. Vonrhein, M. A. Rould, S. J. Everse, A. B. Mason and S. K. Buchanan, J. Biol. Chem., 2006, 281, 24934.

6 R. T. A. MacGillivray, S. A. Moore, J. Chen, B. F. Anderson, H. Baker, Y. G. Luo, M. Bewley, C. A. Smith, M. E. P. Murphy, Y. Wang, A. B. Mason, R. C. Woodworth, G. D. Brayer and E. N. Baker, Biochemistry, 1998, 37, 7919. 
7 S. Bailey, R. W. Evans, R. C. Garratt, B. Gorinsky, S. Hasnain, C. Horsburgh, H. Jhoti, P. F. Lindley, A. Mydin, R. Sarra and J. L. Watson, Biochemistry, 1988, 27, 5804.

8 P. D. Jeffrey, M. C. Bewley, R. T. A. MacGillivray, A. B. Mason, R. C. Woodworth and E. N. Baker, Biochemistry, 1998, 37, 13978.

9 W. R. Harris, C. J. Carrano, V. L. Pecoraro and K. N. Raymond, J. Am. Chem. Soc., 1981, 103, 2231.

10 S. Scapolan, E. Ansoborlo, C. Moulin and C. Madic, Radiat. Prot. Dosim., 1998, 79, 505.

11 I. Llorens, C. Den Auwer, P. Moisy, E. Ansoborlo, C. Vidaud and H. Funke, FEBS J., 2005, 272, 1739.

12 C. Den Auwer, I. Llorens, P. Moisy, C. Vidaud, F. Goudard, C. Barbot, P. L. Solari and H. Funke, Radiochim. Acta, 2005, 93, 699.

13 A. Jeanson, M. Ferrand, H. Funke, C. Hennig, P. Moisy, P. L. Solari, C. Vidaud and C. Den Auwer, Chem. - Eur. J., 2010, 16, 1378.

14 E. Ansoborlo, O. Prat, P. Moisy, C. Den Auwer, P. Guilbaud, M. Carriere, B. Gouget, J. Duffield, D. Doizi, T. Vercouter, C. Moulin and V. Moulin, Biochimie, 2006, 88, 1605.

15 N. Bauer, D. R. Fröhlich and P. J. Panak, Dalton Trans., 2014, 43, 6689.

16 M. Sturzbecher-Hoehne, C. Goujon, G. J. P. Deblonde, A. B. Mason and R. J. Abergel, J. Am. Chem. Soc., 2013, 135, 2676.

17 R. Racine, P. Moisy, F. Paquet, H. Metivier and C. Madic, Radiochim. Acta, 2003, 91, 115.

18 J. Michon, S. Frelon, C. Garnier and F. Coppin, J. Fluoresc., 2010, 20, 581.

19 D. M. Taylor and L. C. Farrow, Nucl. Med. Biol., 1987, 14, 27.

20 D. M. Taylor, J. Alloys Compd., 1998, 271, 6.

21 N. Bauer and P. J. Panak, New J. Chem., 2014, submitted.

22 P. Aisen, A. Leibman and J. Zweier, J. Biol. Chem., 1978, 253, 1930.
23 N. M. Edelstein, R. Klenze, T. Fanghänel and S. Hubert, Coord. Chem. Rev., 2006, 250, 948.

24 I. J. Kim, R. Klenze and H. Wimmer, Eur. J. Solid State Inorg. Chem., 1991, 28, 347.

25 A. B. Mason, W. D. Funk, R. T. A. MacGillivray and R. C. Woodworth, Protein Expression Purif., 1991, 2, 214.

26 Q. Y. He, A. B. Mason, B. A. Lyons, B. M. Tam, V. Nguyen, R. T. A. MacGillivray and R. C. Woodworth, Biochem. J., 2001, 354, 423.

27 T. Kimura and G. R. Choppin, J. Alloys Compd., 1994, 213/ 214, 313.

28 T. Kimura, G. R. Choppin, Y. Kato and Z. Yoshida, Radiochim. Acta, 1996, 72, 61.

29 J. V. Beitz, Radiochim. Acta, 1991, 52-3, 35.

30 J. V. Beitz and J. P. Hessler, Nucl. Technol., 1980, 51, 169.

31 R. Klenze, J. I. Kim and H. Wimmer, Radiochim. Acta, 1991, 52-3, 97.

32 T. Fanghanel, T. Konnecke, H. Weger, P. Paviet-Hartmann, V. Neck and J. I. Kim, J. Solution Chem., 1999, 28, 447.

33 E. Toth, E. Brucher, I. Lazar and I. Toth, Inorg. Chem., 1994, 33, 4070.

34 S. L. Wu and W. D. Horrocks, J. Chem. Soc., Dalton Trans., 1997, 1497.

35 V. Kubicek, J. Havlickova, J. Kotek, T. Gyula, P. Hermann, E. Toth and I. Lukes, Inorg. Chem., 2010, 49, 10960.

36 A. Bremer, A. Geist and P. J. Panak, Dalton Trans., 2012, 41, 7582.

37 R. D. Shannon, Acta Crystallogr., Sect. A: Cryst. Phys., Diffr., Theor. Gen. Cryst., 1976, 32, 751.

38 W. R. Harris, Inorg. Chem., 1986, 25, 2041.

39 J. R. Cooper and H. S. Gowing, Int. J. Radiat. Biol., 1981, 40, 569.

40 D. M. Taylor, J. R. Duffield, D. R. Williams, L. Yule, P. W. Gaskin and P. Unalkat, Eur. J. Solid State Inorg. Chem., 1991, 28, 271.

41 O. Zak and P. Aisen, Biochemistry, 1988, 27, 1075. 